\title{
The Obligation of Judges to Uphold Rules of Positive Law and Possibly Conflicting Ethical Values in Context
}

\author{
The Case of Criminalization of Homelessness in Hungary*
}

Petra Gyöngyi

\section{Introduction}

In June 2018, the National Assembly of Hungary adopted the Seventh Amendment of the Fundamental Law positing that habitually dwelling on public spaces is prohibited. Subsequently, in 2019 the National Assembly enacted Article 133/B of the Criminal Offences Act containing the detailed rules concerning the criminalization of habitual dwelling on public spaces, the application of which is mandatory for judges. Viewed from a theoretical perspective, these legal modifications might give rise to a tension between the constitutional obligation of judges to enforce the law and possibly conflicting professional-ethical standards of conduct.

The obligation of judges to uphold rules of positive law is an important element of judicial functioning in the liberal-democratic tradition. ${ }^{1}$ It is closely connected to the judicial function in the balance of public powers and the decision-making independence of judges. On the one hand, the obligation ties the exercise of the judicial power to legal rules as a primary source. On the other hand, it supports the independent function of judges through the rule-of-law requirements referring to the quality of legislation. ${ }^{2}$ As such, this obligation is also paramount for upholding the ideal of the rule of law, understood at its core meaning of

* I am very grateful for the extremely helpful comments by the editors of this special issue and the anonymous reviewer. Many thanks to Hans Petter Graver for insightful suggestions. I am also indebted to the organizers and participants of the Vereniging voor Wijsbegeerte van het Recht (VWR), Montaigne Centrum and Amsterdam Centre on the Legal Professions 2019 Voorjaarsvergadering, 'Rechterlijke Onafhankelijkheid in het samenspel van constitutionele beginselen', held on the 6 June 2019 in Utrecht for their suggestions on an earlier draft.

1 C.L. de Secondat Montesquieu, The Spirit of the Laws (Cambridge University Press, 1989) (first published 1748), 157.

2 B, Tamanaha, On the Rule of Law (Cambridge: Cambridge University Press, 2004), 122-126. 
reducing the possibility of arbitrary exercise of public power. ${ }^{3}$ In other words, provided that the quality of legislative framework is sustained, a judge can be independent because he/she is bound by the law. Besides domestic legal provisions, international human rights obligations and the EU legal framework help safeguard the substantive rule of law. ${ }^{4}$

In contemporary societies, experiencing an increasing complexity of legal and factual questions, the fundamental values guiding the judicial decision-making process have been incorporated in judicial codes of ethics. ${ }^{5}$ These are non-binding instruments, the normative force of which is different from legal rules and principles. Nonetheless, in a normative sense ethical codes, adopted by judges or judicial councils, provide important moral guidance for the professional activity of judges. This guidance inter alia might entail clarifications regarding the fulfillment of the judicial obligation to uphold rules of positive law. ${ }^{6}$ In this sense, the purpose of ethical codes is to motivate judges towards better performance. At the same time, ethical codes also have an accountability role, in the sense of limiting professional activities of judges to be in line with the prescribed values. ${ }^{7}$ The additional guidance provided by ethical codes appears useful, for example, for new judges or for deciding complex cases, such as ones emerging in the fields of criminal law, administrative law and family law.

However, at times, the formal obligation of judges to uphold rules of positive law may collide with possibly conflicting ethical values of judges. Consider, for example, the field of criminal law. Here, it is possible to talk about the

3 M. Krygier, 'Four Puzzles about the Rule of Law: Why? What? Where? And Who Cares?', in Getting to the Rule of Law, ed. J.E. Fleming (New York: New York University Press, 2011), 78. P. Selznick, “'Law in Context” Revisited,' Journal of Law and Society 33 (2003), 177. 179. M. Krygier, 'The Rule of Law. Legality, Teleology, Sociology' in Relocating the Rule of Law, eds. G. Palombella and N. Walker (Portland, OR: Hart Publishing, 2009), 69,70. P. Selznick, 'Legal Cultures and the Rule of Law', in The Rule of Law After Communism. Problems and Prospects in East-Central Europe, eds. M. Krygier \& A.W. Czarnota (Dartmouth: Ashgate, 1999), 21-38. M. Krygier, 'The Rule of Law. An Abuser's Guide', in Abuse: The Dark Side of Fundamental Rights, ed. A. Sajó (The Hague: Eleven International Publishing, 2006), 3-24.

4 E. Mak \& S. Taekema, 'The European Union's Rule of Law Agenda: Identifying its Core and Contextualizing Its Application', Hague Journal on the Rule of Law 8 (2016), 25-50.

5 M. Simonis, 'The Role of Judicial Ethics in Court Administration: From Setting the Objectives to Practical Implementation,' Baltic Journal of Law and Politics 10 (2017), 1, 90-123. 97-101. E. Mak, 'Researching judicial ethical codes, or: how to eat a mille-feuille?,' International Journal of Court Administration 9 (2018), 55-66. E. Mak, N. Graaf \& E. Jackson, 'The Framework for Judicial Cooperation in the European Union: Unpacking the Ethical, Legal and Institutional Dimensions of "Judicial Culture", Utrecht Journal of International and European Law 34 (2018), 1, 31-34. G. di Federico, 'Judicial Accountability and conduct: An Overview', in Judicial Independence in Transition, ed. A. Seibert-Fohr, (Heidelberg: Springer, 2012), 87-118.

6 See e.g. France: CSM, Recueil des obligations déontologiques des magistrats (Paris: Dalloz, 2010), www.conseil-superieur-magistrature.fr/sites/default/files/atoms/files/recueil_des_obligations_ deontologiques_des_magistrats_3.pdf (accessed 27 September, 2019) Chapter 4. Romania: SCM Deontological Code for Judges and Prosecutors, 2005, Art 3(2), http://old.csm1909.ro/csm/ linkuri/26_09_2005_823_ro.pdf (accessed 27 September, 2019).

7 A. Hol \& M. Loth, Reshaping Justice. Judicial Reform and Adjudication in the Netherlands (Maastricht: Shaker, 2004), 85, 86. 
criminalization of certain social behaviours, which constitute subversion or perversion of criminal law. Perversion of criminal law refers to situations where criminal law is 'used for purposes that are not are proper to it, or in ways that violate the values which should structure it'. Whereas, subversion of criminal law refers to situations when 'a conduct that should be dealt by criminal law is dealt with by other modes of legal control'. ${ }^{8}$ The criminalization of homelessness serves as a good example of the current tensions between the constitutional obligation of judges to uphold rules of positive law and to act in compliance with the ethical guidelines, in legal environments where the rule of law is under stress, as it represents an area of possible perversion of criminal law.

In these situations, a relevant practical question for judges from an ethical perspective is how they can distance themselves in their statements in a legitimate way from legal rules, which are in conflict with the rule of law. In this exercise, judicial virtues, such as professional courage and judicial justice might come into play for realizing moral and rule of law quality in adjudication. Judicial courage would refer to situations when a judge explicitly speaks up against a legal rule that goes against the rule of law. Judicial justice is a virtue that concerns the relation between the judge and society at large and it refers to the 'disposition of a judge to secure the values of political morality'. ${ }^{9}$ Ethical codes for judges may have a role in supporting the internalization and exercise of these virtues in a legitimate way. For instance, the Magna Carta of Judges explains under the heading of 'Rule of Law and Justice' that the judiciary's mission is 'to guarantee the very existence of the Rule of Law, and, thus, to ensure the proper application of the law in an impartial, just, fair and efficient manner'. ${ }^{10}$

While these tensions have been explored before in the context of established democracies $^{11}$ and in case of theoretical and historical analysis of legal orders undergoing extreme pressure, ${ }^{12}$ there is no similar analysis concerning new liberal-democracies within the European Union. ${ }^{13}$ A separate analysis appears necessary because, on the one hand, in these countries we cannot speak of a well-

8 R.A. Duff, 'Perversions and Subversions of Criminal Law', in The Boundaries of Criminal Law, eds. R.A. Duff, Lindsay Farmer, S.E. Marshall, Massimo Renzo \& Victor Tadros (Oxford: OUP, 2011), 92.

9 I. van Domselaar, 'Moral Quality in Adjudication', Netherlands Journal of Legal Philosophy 44 (2015), 1, 24-46. 31, 32, 33.

10 Consultative Council of European Judges, Magna Carta of Judges, Fundamental Principles.

11 See e.g. J. Brand-Ballard, Limits of Legality. The Ethics of Lawless Judging (Oxford: OUP, 2010). A. Reeves, 'Do Judges Have an Obligation to Enforce the Law? Moral responsibility and judicial reasoning', Law and Philosophy 29 (2010), 2, 159-187.

12 E.g. G. Radbruch, 'Gesetzliches Unrecht und Ubergesetzliches Recht', Süddeutsche Juristen-Zeitung (1946), 1, 105-108 ('Statutory Lawlesness and Supra-Statutory Law' (translated by B. Litschewski Paulson and S.L. Paulson) Oxford Journal of Legal Studies 26 (2011), 1, 1-11). D. Dyzenhaus, Hard Cases in Wicked Legal Systems (Oxford: Oxford University Press 2nd edition, 2010). H.P. Graver, Judges Against Justice. On Judges When the Rule of Law is Under Attack (Heidelberg: Springer, 2015).

13 For an evaluation between the concepts of judicial independence, impartiality and accountability see A. Sajó ed., Judicial Integrity, (Leiden: Brill, 2004). 
established rule of law normative framework and related conventions. As such, offering additional guidance to judges concerning their professional role, inter alia through ethical codes, is of heightened importance. On the other hand, we are experiencing current and severe attacks on the rule of law in the Central and Eastern European region. However, as Member States of the European Union and the Council of Europe, it remains questionable whether the nature of these tensions can be directly comparable to historical examples.

At the same time, these challenges also put the theoretical conceptualization of rule of law development to the test. Indeed, a predominant theoretical framework used for understanding legal developments in the Central and Eastern European region since the fall of communism constituted the rule of law theory developed by Phillip Selznick and Martin Krygier. ${ }^{14}$ Notwithstanding differences in the details of these theories, ${ }^{15}$ the two main common elements constitute (1) the core conceptualization of the rule of law value as the reduction of arbitrary exercise of public power, which must be understood progressively as an ever-increasing development and (2) an emphasis on the context-specific implementation of the rule of law value. Indeed, the 'teleological' approach of these theories, focusing on the purpose of the rule of law value seemed particularly adept to frame theoretical discussions in the Central European region with no well-established rule of law tradition and where the main objective of the rule of law ideal had to be defined. Moreover, the contextual approach provided a necessary flexibility of rule of law discussions at the regional level, displaying societal, historical and economic differences.

Despite the unquestionable merits of these theories, the 'rule of law backsliding'16 experienced in EU Member States such as Hungary and Poland, put the applicability of the understanding of the realization of the rule of law as a progressive reduction of arbitrariness and as an ever-increasing exercise to the test. This element is characteristic to Selznick's work. Indeed, his theory, which is mainly concerned with the functioning of law in society, focuses on the transition from 'repressive law' (characterized by the interconnection between law and politics) to 'autonomous law' (characterized by the rule of law and where the formality and integrity of law is crucial) and towards 'responsive law' (where law is linked to policy). ${ }^{17}$ Selznick's theory acknowledges the existence of possible threats to the autonomy of law and conditions of weak cultural settings. For instance, according to him 'blurring lines between law and politics' can 'become

14 See e.g. Selznick, 'Legal Cultures and the Rule of Law' (1999), 21-38. J. Waldron ed., 'Martin Krygier's Passion for the Rule of Law (and his Virtues)', Hague Journal on the Rule of Law 11 (2019), 2-3.

15 See S. Taekema, 'Two Realists Theorizing the Rule of Law', Hague Journal on the Rule of Law 11 no. 2-3 (2019), 301-306, 302, 303.

16 See M. Bánkuti, G. Halmai \& K. L. Scheppele, 'Disabling the Constitution', Journal of Democracy 23 (2012), 138. L. Pech \& K. L. Scheppele, 'Illiberalism Within: Rule of Law Backsliding in the EU', Cambridge Yearbook of European Legal Studies 19 (2017), 3. 11-17. See further note 89.

17 P. Nonet \& P. Selznick, Law and Society in Transition. Towards Responsive Law (Originally published in 1978 by Harper Torch Books) (New York: Routledge, 2017), 103-152. 
pernicious when legal rules and decisions mainly serve the interests of dominant elites' ${ }^{18}$ Furthermore, his theory accepts the possibility of the co-existence of repressive law with autonomous and responsive law within a single legal system. ${ }^{19}$ However, it remains an open question to what extent this theory can capture experiences of systemic rule of law backsliding. A further question concerns the type of guidance this theoretical framework can provide to overcome these challenges.

The present analysis aims to address the above-described practical and theoretical problems by examining the constitutional tensions created by the criminalization of homelessness in Hungary during the period 2010-2018. Following this introduction, section 2 of the analysis will explain the content of the constitutional obligation of judges to uphold rules of positive law in Hungary. This analysis will be complemented in section 3 by an assessment of the ethical guidelines applicable for the judicial decision-making process. Section 4 of the article will present the legal developments corresponding with the criminalization of homelessness in the Hungarian legal order, taking place since 2010. Section 5 describes the application by judges of the new legal provision criminalizing homelessness and the related decision by the Constitutional Court from 2019. Based on the above information, section 6 contains a critical assessment concerning the tensions that arise due to this criminalization between the constitutional obligations of judges to uphold the law and possibly conflicting ethical values of judges. This section also discusses the implications of these legal changes for the progressive and context-specific realization of the rule of law principle in Hungary. Section 7 concludes by highlighting the implications of the situation in Hungary for the theoretical understanding of the progressive realization of the rule-of-law principle.

\section{The Constitutional Obligation of Hungarian Judges to Apply Rules of Positive Law}

In the Hungarian legal order, the obligation of judges to apply rules of positive law is codified in the text of the Fundamental Law, enacted in April 2011.20 Article 26 of the Fundamental Law contains the general guarantee of judicial independence by establishing that "judges shall be independent and only subordinated to Acts'. ${ }^{21}$ By connecting independent judicial functioning to legal acts, the Fundamental Law protects the independent decision-making of judges while at the same time establishing the obligation of judges to uphold rules of positive law. In the Hungarian legal order, following the continental law 178.

19 Nonet \& Selznick, , Law and Society in Transition. Towards Responsive Law (2017), 76-78.

20 Magyarország Alaptörvénye (Fundamental Law of Hungary), Official Journal 100 of 29 June 2018, 5106.

21 Fundamental Law of Hungary, Art. 26. 
tradition, ${ }^{22}$ this obligation mainly refers to legal acts. ${ }^{23}$ As a further guarantee of decision-making independence, Article 26 of the Fundamental Law prohibits the instruction of judges in relation to their judicial activities. The form of this constitutional guarantee is also general as it prohibits influence of any nature on the decision-making independence of judges. ${ }^{24}$

The Constitutional Court, with its exclusive competence in the Hungarian legal order to decide on questions of constitutionality, has clarified the meaning of these general guarantees since its establishment in 1990. However, with regards to constitutional case law it must be mentioned that the Fourth Amendment of the Fundamental Law in 2013 nullified the case law of the Constitutional Court between 1990 and 2011. ${ }^{25}$ Despite this important limitation, the case law of the Constitutional Court is useful for analyzing the progressive development of the decision-making independence of judges in Hungary.

Firstly, concerning the obligation of judges to decide cases on the basis of legal acts, the Constitutional Court declared that this obligation constitutes an important limitation on the independence of judges. ${ }^{26}$ In the opinion of the Constitutional Court, this obligation not only constitutes a limitation, but it is also the very basis of the judicial decision-making function. As such, the Court considered that the requirement of judges being subject to the law was a key condition for judicial independence, considering the function of judges to 'autonomously interpret legislation adopted by the political branches of the Government'. ${ }^{27}$ Here, there is a strong connection between autonomous interpretation by judges and following positive rules adopted by the legislature.

Secondly, these clarifications with regards to the obligation of judges to uphold positive law are connected to broader considerations of decision-making independence. For instance, the case law by the Constitutional Court clarified the meaning of prohibition of both external and internal pressures on judicial decision-making. Indeed, the Constitutional Court established that the protection against any influence on judicial decision-making extends to possible influence emerging from the political branch of Government, as well as internal pressures. According to the Court, internal independence entails two elements. On the one hand, internal independence must be guaranteed vis-à-vis other judges. In other words, it must be guaranteed that judges decide cases based on their own

22 H.P. Glenn, Legal Traditions of the World: Sustainable Diversity in Law, (Oxford: Oxford University Press, 2014), Chapter 5.

23 M. Bencze, Elvek és Gyakorlatok. Jogalkamazási minták és problémák a magyar bírói értelmezésben [Principles and Practices. Examples and problems of law application in the Hungarian judicial interpretation] (Budapest Debrecen: Gondolat, 2011) 127-153.

24 Fundamental Law of Hungary, Art. 26 (2).

25 Fourth Amendment of the Fundamental Law, adopted on 11 March 2013. The Fundamental Law of Hungary, including the modifications introduced by the Fourth Amendment, Official Journal 55 of 1 April 2013, 14584. Act XX of 1949 The Constitution of Hungary as amended 1989-1990 and subsequent amendments, Official Journal 15023 October 2009, 38614-38633.

26 Constitutional Court of Hungary, Decision 53 of 1991, 266, 267. Decision no. 3154/2017, 19.

27 Constitutional Court of Hungary, Decision 53 of 1991, 266, 267. Decision no. 3154/2017, 19. 
professional opinion. On the other hand, the possibility of undue influence by the administration must be ruled out. ${ }^{28}$

The case law of the Constitutional Court following the Fourth Amendment of the Fundamental Law also refers to the notion of decision-making autonomy. For instance, the decision by the Constitutional Court concerning the forced early retirement of judges in 2011, established that 'the irremovability of judges as secured by the Fundamental Law is, among others, such a personal guarantee which secures the decision-making autonomy of judges, as it excludes the possibility of judges to suffer retaliation because of a judgment rendered in accordance with the laws and their own conscience' ${ }^{29}$ Here, we can note references to possible conflicts between the independent and autonomous interpretation of legal rules and the obligation of judges to follow positive law, which could result in retaliation against judges. At the same time, the formulation maintains a reference for the role of judges to render decisions both in line with rules of positive law and also in line with their own conscience, offering an extended reading of the sphere of judicial decision-making. ${ }^{30}$

Next to the obligation of judges to uphold legal acts, Article 28 of the Fundamental Law further guides the interpretation of legal acts by judges. This provision was explicitly incorporated in the text of the constitution in 2011 with the adoption of the Fundamental Law and it was modified in 2018 with the Seventh Amendment of the Fundamental Law. ${ }^{31}$ The first sentence of Section 28 of the Fundamental Law stipulates that courts should be independent in the application of the law. In this sense, it refers to the decision-making independence of judges guaranteed in Article 26.

However, this constitutional provision also contains specifications regarding the interpretation of legal acts. This is the part of the legal provisions, which has been subject to incremental modifications between 2011 and 2018. According to the original version of Article 28, adopted in 2011, courts have an obligation to interpret legal acts 'primarily in accordance with their purposes and in line with the Fundamental Law'. ${ }^{32}$ In addition, the 2011 version of Article 28 explicitly stated that in the interpretation of the Fundamental Law or legislation in general, judges must presume that the legal texts serve 'moral and economic purposes which are in accordance with common sense and the public good'. ${ }^{33}$

Constitutional Court of Hungary, Decision 33 of 2012 (VII.17.) AB, para. 84.

See section 3 of this article.

Seventh Amendment of the Fundamental Law, May 2018.

'In the course of the application of law, courts shall interpret the text of laws primarily in accordance with their purposes and with the Fundamental Law. When interpreting the Fundamental Law or laws, it shall be presumed that they serve moral and economic purposes which are in accordance with common sense and the public good'. See further Art. 24 (2) Fundamental Law on constitutional complaint.

Fundamental Law of Hungary, Art. 28. 
At the time of the incorporation of this provision in the text of the constitution, legal scholarly analysis deemed the enactment of Article 28 a positive development as it explicitly acknowledged objective teleological interpretation (or purposive interpretation). ${ }^{34}$ In so doing, it was considered that Article 28 formally confirmed the legal position of objective teleological interpretation, which is considered as the established form of judicial interpretation in the Hungarian legal order. Indeed, the Constitutional Court has acknowledged the importance of the functional interpretation of legal acts before. ${ }^{35}$ Moreover, legal scholarly analysis has considered objective teleological interpretation as a longterm Hungarian judicial tradition, which experienced a discontinuity during communism. ${ }^{36}$ At the same time, the legal literature strictly delimited objective teleological interpretation, through which judges take into account the general aims behind a given legislation and subjective teleological interpretation, by which judges would be obliged to take into account the objectives of the specific legislators, who adopted a legal act. ${ }^{37}$

However, the Seventh Amendment of the Fundamental Law adopted in June 2018 further changed the content of Article 28 concerning judicial interpretation. ${ }^{38}$ Regarding the meaning of the interpretation of legal acts in light of their 'purposes', the modified version of Article 28 explicitly adds that legal acts should be interpreted in light of the Preamble of the legal act as well as the arguments contained in the preparatory documents for the adoption or modification of the legal act. ${ }^{39}$ As such, the Seventh Amendment further determined what exactly should be understood concerning 'the purposes of a legal act'.

The explanation contained in the legislative preparatory documents also supports this limited interpretational room of judges. These documents established that in the course of teleological interpretation, judges must primarily take into account the legislative aims established by the legislature. Further, the reasoning also pointed out that the preamble of the legal act as well as the arguments for the adoption or modification of legal acts constitute a 'complete and authentic source' for establishing the legislative aims. Although the preparatory documents mention that the indicated sources are not exclusive, the list of possible sources remains limited. For instance, the preparatory documents mention the following

34 See A. Jakab., 'A bírói jogértelmezés az Alaptörvény tükrében' (Judicial Interpretation in light of the Fundamental Law), Érveléstan-Érveléstechnika JeMa 4 (2011), 86-94. A. Barak, Purposive Interpretation in Law (Princeton, Princeton University Press, 2005), xi.

35 Constitutional Court of Hungary, Decision no. 18/2008 (III.12.) AB, 267, 271.

36 Bencze Elvek és Gyakorlatok. Jogalkamazási minták és problémák a magyar bírói értelmezésben (2011), 127-153. See also M. Matczak, M. Bencze \& Z. Kühn, 'Constitutions, EU Law and Judicial Strategies in the Czech Republic, Hungary and Poland,' Journal of Public Policy 30 (2010), 1, 81-99.

37 Jakab, 'A bírói jogértelmezés az Alaptörvény tükrében' (Judicial Interpretation in light of the Fundamental Law) (2011), 89-91.

38 Seventh Amendment of the Fundamental Law, 28 June 2018, Art. 8.

39 Fundamental Law of Hungary, Art. 28. 
as further sources of interpretation: arguments made during the legislative process, achievements of the historical constitution and legal scholarship. Moreover, the preparatory document also posits that the National Assembly enjoys a wide margin of discretion as to what considerations should be made public within the legislative preparatory documents. ${ }^{40} \mathrm{~A}$ problematic point here could be the introduction of subjective teleological interpretation, ${ }^{41}$ which would reduce the legitimate room of interpretation of judges and replace it with the considerations, aims and values of the legislators adopting the legal act, rather than exploring the objective goal behind a legal regulation.

Article R of the Fundamental Law further exacerbates this constitutional tension. The 2011 Fundamental Law also introduced this constitutional provision and it provides guidance regarding the interpretation of the Fundamental Law. In particular, this provision becomes relevant in light of the obligation of judges to take into account the Fundamental Law in the interpretation of legal provisions, pursuant to Article 28. Article R establishes the Fundamental Law as the basis of the Hungarian legal order and pronounces that the Fundamental Law and rules of positive law are mandatory for everyone. With reference to the interpretation of the Fundamental Law, according to Article $\mathrm{R}$ the text of the Fundamental Law should be interpreted: (1) in line with its aims, (2) the National Avowal incorporated in the text of the constitution and (3) the achievements of the historical constitution of Hungary. As such, similar to Article 28, Article R also explicitly lists the legislative sources that must be taken into account for the interpretation of the Fundamental Law. Moreover, the Seventh Amendment of the Fundamental Law in 2018 added sub-paragraph 4 to Article R, which establishes that every public institution has an obligation to promote the constitutional identity of Hungary and to protect the Christian culture of Hungary. By extension, judges are also obliged to do so.

At the same time, the values of the rule of law, ${ }^{42}$ separation of powers, principles of good lawmaking and fundamental rights constitute an explicitly codified part of the Fundamental Law. When the Fundamental Law stipulates that the constitution is the basis of the Hungarian legal order, it also refers to these values. As such, these legal principles and values continue to remain part of the formal basis for rendering judicial decision in accordance with the Fundamental Law. However, tensions might arise between the new set of constitutional values. For instance, the protection of the Christian culture of Hungary may result in tensions with regard to guaranteeing human dignity or the rule of law value.

Through these sequential constitutional modifications, the governing majority significantly reduced the legitimate space of judges to rely on legal rules and their

40 Government of Hungary, Proposal no T/332 for the Seventh Amendment of the Fundamental Law, May 2018, detailed arguments concerning Art. 7, 7.

41 Jakab 'A bírói jogértelmezés az Alaptörvény tükrében' (Judicial Interpretation in light of the Fundamental Law) (2011), 89-91.

42 Fundamental Law of Hungary, Article B(1), Art. C(1). 
'conscience'43 in interpreting legislation. The current formulation leaves limited room, for instance, to the meaning of legal provisions as established by the Constitutional Court through its case law; an institution which in Hungary holds an important role in clarifying the meaning of the constitutional text. ${ }^{44}$ In a similar vein, societal circumstances, contemporary developments, but also any constitutional conventions fall outside the ambit of these guidelines.

The threat here is to reduce judicial interpretation into a mechanical exercise, a heritage from which the Hungarian legal order aimed to move away after the fall of communism. The incorporation of this guidance at the level of the Fundamental Law adds particular weigh to this restricted interpretational room for judges. The following section will discuss the extent to which this modified constitutional frame of reference concerning the obligation of judges to uphold rules of positive law may enter in conflict with ethical values of judges.

\section{Guidance by Judicial Codes of Ethics}

In the Hungarian legal order, the ethical values guiding judges in their professional activities as well as their general conduct in society are incorporated in a judicial code of ethics, adopted by the National Judicial Council (NJC) in 2014 - pursuant to its new legal power. ${ }^{45}$ The 2014 ethical code replaced the judicial code of ethics adopted in 2005 by the Hungarian Association of Judges one of the main judicial associations in Hungary. ${ }^{46}$ As such, the adoption of the new ethical code is closely intertwined with the broader reforms concerning the organization of the judiciary, taking place since 2011. ${ }^{47}$ Indeed, the process of revising the judicial code of ethics was initiated in 2012, by the President of the National Judicial Office (NJO) - the head of a newly established judicial institution in charge of the management of the judiciary. In particular, the revision of the judicial code of ethics was part of the 'key strategic goal' of enhancing judicial integrity. ${ }^{48} \mathrm{~A}$ special working group within the National

43 Constitutional Court of Hungary, Decision 33/2012 (VII.17.) AB, para. 84.

44 See Fundamental Law of Hungary, Art. 24.

45 Judicial code of ethics adopted on the 10th of November 2014 by the National Judicial Council of Hungary and entered into force on the 1st of January 2015, https://birosag.hu/sites/default/ files/3_etikai_kodex.pdf (accessed 27 September 2019).

46 Z. Fleck, 'Judicial Independence in Hungary', Judicial Independence in Transition, ed. A. SeibertFohr, (Heidelberg: Springer, 2012), 825.

47 K. Kovács \& K. L. Scheppele, 'The fragility of an independent judiciary: Lessons from Hungary and Poland - and the European Union', Communist and Post-communist Studies 51 (2018), 189-200, 191-194.

48 Summary of the processes leading to the adoption of the 2015 ethical code available at https:// birosag.hu/a-birosagi-szervezet/orszagos-biroi-tanacs-2/biroi-etika (accessed 27 September 2019). Main strategic goals of the President of the National Judicial Office available at https:// birosag.hu/beszamolok/az-orszagos-birosagi-hivatal-elnokenek-beszamoloja-2012-i-felev (accessed 27 September 2019). 
Judicial Office, composed of judges appointed by the President of the NJO developed the first draft of the new ethical code. ${ }^{49}$

The President of the Judicial Integrity workgroup mentioned two main grounds for the adoption of a new judicial ethical code. One argument was that not all judges could relate to the content of the 2005 ethical code since not all judges in the Hungarian legal order were members of the association. ${ }^{50}$ The second argument was that in the course of ten years since the adoption of the 2005 ethical code, the organization of the judiciary and the judicial function underwent rapid changes, endorsing new values. In the opinion of the workgroup, the ethical code had to adequately reflect these changes. ${ }^{51}$ The announcement specifically mentioned that the relation between judicial independence and the role of media as well as the use of the Internet required novel guidance. ${ }^{52}$ However, after the formal empowerment of the National Judicial Council in 2013 to adopt the judicial code of ethics, ${ }^{53}$ the NJO transferred the preparations for the adoption of a new ethical code to the NJC.

In 2014, the National Judicial Council appointed a new workgroup composed of judges working at the National Judicial Office (3), judges from the National Judicial Council (3), judge-members of the association of judges (3), as well as the presidents of the first and second instance civil service tribunals. This workgroup finalized drafting the ethical code. The process included three consultative sessions with judges - where judges could comment on the draft version. ${ }^{54}$ However, the NJC did not publish the draft version and the content of observations by judges.

In terms of content, the Preamble of the Hungarian Judicial Code of Ethics refers to the constitutional role of judges and the expected high quality of judging, by establishing that 'in line with the Fundamental Law, the judiciary consists of independent and irreproachable judges and fulfills its constitutional role through a transparent judicial system'. ${ }^{55}$ The Preamble also clearly states that the nature of judicial profession entails more stringent ethical norms for judges than the ethical norms generally applicable in society. Moreover, the Preamble clarifies that the main purposes for the Ethical Code were (1) to enhance the public's confidence in the judiciary by establishing the applicable ethical norms to judges; (2) to establish as guidance the ethical requirements of the judicial profession;

49 National Judicial Council, Decision 20/2014 establishing the workgroup for developing the ethical code, https://birosag.hu/sites/default/files/20.pdf (accessed 27 September 2019).

50 Interview with dr. Túri Tamás, vice-president of the Pécs Regional Court and the President of the 'Judicial Integrity' workgroup responsible to develop the new ethical code (Interview published on the official website of the National Judicial Office), https://birosag.hu/sites/default/files/ interju_dr._turi_tamassal_2.pdf (accessed 27 September 2019).

51 Ibid.

52 Ibid.

53 Act CLXI of 2011 on the organization and administration of courts, Art. 103 (1).

54 Information on the conferences available at https://birosag.hu/a-birosagi-szervezet/orszagosbiroi-tanacs-2/biroi-etika/konferenciak (accessed 27 September 2019). 
(3) to provide support in revealing certain behaviors that hold within ethical risks, and (4) to protect judges who display a conduct that is worthy to their profession.

With regard to judicial decision-making, Article 1 of the Ethical Code further shapes the legitimate space for judges in deciding cases by explaining the meaning of the value of judicial independence. As a dimension of the value of judicial independence, the Ethical code states that judges enjoy freedom when deciding cases, within the boundaries of substantive and procedural law and in line with their own conscience. ${ }^{56}$ Through this formulation, this provision follows the constitutional obligation of judges to subject their professional activities to positive legal rules. ${ }^{57}$ However, at the same time its content aligns with the interpretation of the Constitutional Court stipulating that judges should decide based on their conscience. ${ }^{58}$ Here lies tension between the current content of the constitutional text and ethical values, because the conscience of judges and, indeed, the value of the rule of law might be more expansive than the 'moral, economic and rational purposes' and the Christian values prescribed by the Fundamental Law. ${ }^{59}$

Another provision of relevance for the decision-making independence and autonomy of judges is the value of mutual respect and cooperation elaborated upon under Article 6. This value mainly addresses the behavior of judges in the courtroom and it incorporates several distinct dimensions. The first dimension of this value calls judges to respect every person's dignity, without prejudice or discrimination. Moreover, judges are expected to demand such behaviour from parties to a trial and their legal representatives. ${ }^{60}$ As an additional dimension of the value of mutual respect and cooperation, judges cannot criticize the instructions provided by higher courts in front of parties to a trial. Moreover, judges cannot express their different opinion from that of a higher court and they cannot openly criticize decisions by other courts. ${ }^{61}$ These provisions further emphasize the role of judges to respect human dignity in the exercise of their professional duties, an important part of which constitutes the judicial decisionmaking process. At the same time, the ethical code also emphasizes the importance for judges to respect decisions by other courts.

Overall, the judicial code of ethics further clarifies the values and considerations which judges must take into account when deciding cases. However, the simultaneous obligation to respect human dignity of parties to a trial and to comply with the decisions of other courts might lead to tensions in specific cases. According to the text of the ethical code, judges must overcome these possible tensions by respecting the decisions of higher courts and by refraining to form a

56 Judicial Code of Ethics, Preamble, Art. 1.

57 Fundamental Law of Hungary, Art. 26.

58 Constitutional Court of Hungary, Decision 33 of 2012.

59 See above, section 2 of this article.

60 Judicial Code of Ethics 2014, Art. 6.

61 Judicial Code of Ethics 2014, Art. 6. 
public opinion about decisions by their colleagues within the courtroom. Taking these guidelines into account, it remains to be seen in the following section what specific tensions occur in upholding the legal provisions concerning homelessness.

\section{The Criminalization of Homelessness in Hungary}

The criminalization of homelessness has been a recurring subject on the legislative agenda in Hungary since 2010. First, in 2010 the Municipality of Budapest sanctioned repeated violations of habitual dwelling in public places and designated so-called 'homeless-free' zones. ${ }^{62}$ This was followed by a modification of the Criminal Offences Act through which the legal ban was extended to all municipalities. ${ }^{63}$

Originally, through Decision 38 of 2012, the Constitutional Court declared the provision of the Criminal Offences Act unconstitutional. The Court annulled the legal provision on the basis of violation of Article II of the Fundamental Law protecting the value of human dignity. Indeed, the Court declared that the removal of homeless persons from public spaces and the encouragement of persons in need to participate in the social benefits system do not constitute legitimate constitutional aims that could serve as a basis for criminalizing homelessness.

Instead of a problem pertaining to the field of criminal law, the Court considered homelessness to be a social problem. In the Court's opinion, the State should rely on the means of social services and social benefits to tackle this problem instead of criminalization. Specifically, the Court found contrary to human dignity to declare socially dangerous an entire group of persons based on the shared characteristics of losing their homes and being compelled to live on public spaces. In a similar vein, the Court also found that compelling individuals to participate in social benefits systems was in violation of the freedom of action, emerging from the value of human dignity. ${ }^{64}$ From a theoretical perspective, the Constitutional Court considered the criminalization of homelessness a perversion of criminal justice. The problem was not banning homelessness as such, but rather doing so through the means of criminal law, which constitutes a perversion of criminal law. ${ }^{65}$

Going against the Constitutional Court's decision, the governing majority neutralized the annulment through the modification of the constitutional text.

63 Act II of 2012, Art. 186. Art. 146 of the Offences Act in force before the 2012 stipulated that local government have the possibility to adopt an ordinance sanctioning habitual dwelling in public spaces. In case of repeated violations of a local ordinance, individuals could be fined or detained.

64 Constitutional Court of Hungary, Decision 38 of 2012 (XI.14.) AB, 204 [53].

65 See Duff, 'Perversions and Subversions of Criminal Law' (2011). 
Indeed, with the Fourth Amendment of the Fundamental Law in 2013, the criminalization of homelessness was incorporated in the Fundamental Law. The amendment introduced in the first sub-paragraph of Article XXII Hungary's commitment to strive to secure decent housing conditions and access to social services to everyone. In sub-paragraph two the constitutional amendment specified that this commitment refers to the commitment of the State and local authorities to secure housing for individuals without a dwelling.

Importantly, the Fourth Amendment introduced at the level of the Fundamental Law the possibility for local governments to adopt a decree through which they could declare specific parts of public spaces as areas where habitual dwelling is prohibited. The reasons for such decisions, according to the constitutional provision, included the protection of public order, public security, public health and cultural values. ${ }^{6}$ As such, the Fundamental Law enabled municipalities to decide on the criminalization of homelessness. Indeed, for instance, the capital of Budapest adopted such a decree. ${ }^{67}$ Administrative authorities in Budapest and other local public authorities started proceedings against individuals violating this ban. ${ }^{68}$

In addition to these, with the Seventh Amendment of the Fundamental Law in June 2018, this matter became an important concern for courts and judges. This amendment re-incorporated in the constitutional text the general prohibition of habitual dwelling in public spaces by reformulating the content of the third subparagraph of Article XXII. The new provision declares that it is forbidden to live on public spaces on a permanent basis' ${ }^{69}$ With this modification, the prohibition of habitual dwelling in public spaces was transformed from an optional measure left at the discretion of local governments, into a mandatory one. As such, the geographical scope of the criminalization has been extended to the entire country.

Indeed, following the Seventh Amendment of the Fundamental Law, Act XLIV of 2018 renamed Article 133/B to 'violation of the rules pertaining to habitual dwelling in public spaces' and introduced Article 178/B which establishes that habitual dwelling in public spaces constitutes an offence. When deciding these cases, judges may issue a warning, order community work or detention. ${ }^{70}$ The motivation of the legal act clarified that the introduction of this provision was

66 Fourth Amendment of the Fundamental Law, 2013 March 25, Art. 8.

67 Ordinance no. 77/2013 (XII.3.) Főv. Kgy. (designating 'homeless-free zones').

68 An estimation of a civil society organization protecting the homeless, based on public information requests addressed to the Government and National Police Services, indicates 505 administrative procedures between October 152013 and 30 September 2018, https:// avarosmindenkie.blog.hu/2019/01/15/eletvitelszeru_kozteruleten_tartozkodas_miatt_inditott_ szabalysertesi_eljarasok_statisztika?token=5e554a9c09224f70926a154d3ae92d2b\#more 5653334 (accessed 29 September 2019).

69 Seventh Amendment of the Fundamental Law, 28 June 2018, Art. 6.

70 Act XLIV of 2018 on the modification of Act II of 2012 on offences, procedure and the offences registration system, Official Journal no. 122 of 2018, Art. 6 (1, 2). 
necessary in order to secure coherence with the constitutional frame of reference. ${ }^{71}$

With the Seventh Amendment, the constitutional ban and the subsequent article of the Offences Act became rules of positive law in the application of which judges are bound by interpretation rules posited in Article 28 of the Fundamental Law. ${ }^{72}$ In light of these changing interpretational rules, the question occurs what room is left for decision-making independence and the autonomy of judges to decide in line with their conscience and judicial virtues. A broader concern is to what extent these constitutional and legal developments are in line with the progressive realization of the rule of law in Hungary.

\section{The Approach of Judges and the 2019 Decision of the Constitutional Court}

The judgments by first instance courts in these cases display different approaches by judges to legitimately distance themselves from the legal ban on homelessness, going against the rule of law ideal and, in doing so, to display the virtues supported by the ethical code. A first possible approach relied on argumentation as a tool for dismissal. This approach could be for instance traced in a judgment issued by the Court of Pécs in 2018. Here, the judge dismissed the case holding that the person in question cannot be deemed 'homeless' because, although the person did not have a flat or a house, the person nonetheless had a place to stay and as such was not homeless. ${ }^{73}$ In doing so, the judge relied on his/her decisionmaking autonomy for defining the notion of homelessness, on which the applicability of the legal provision depended. Originally, the case was dismissed and no appeal was filed against this decision.

However, certain aspects of this case that rendered this judgment possible must be highlighted. Firstly, this was the fourth case deciding on the application of the provision criminalizing homelessness. Indeed, the judge explicitly pointed out that the legal provision has become recently applicable and as such there was no established understanding as to what type of warnings fulfilled the legal requirements. Secondly, the judge also highlighted that this case did not occur in the capital but rather in a provincial area, where the extent of homelessness is more reduced. In so doing, from the perspective of the ethical values, ${ }^{74}$ the court struck a balance between respecting the judgments of other courts and considering with professionalism the circumstances of the case at hand in the application of the legal provision.

71 Government of Hungary, Proposal T/7708 on the modification of the Offences Act.

72 See above, section 3 of this article.

73 On the decision of the Pécs First Instance Court, see https://szabadpecs.hu/2018/10/ megszuntettek-a-pecsi-hajlektalannal-szemben-inditott-szabalysertesi-eljarast/ (accessed 27 September 2019). 
The other group of judgments elaborated upon the tensions between the constitutional value of human dignity and fundamental rights protection raised by the provision criminalizing homelessness. Judges in these cases complied with the obligation to refer the case to the Constitutional Court for further deliberation. ${ }^{75}$ For instance, the Court of Kaposvár highlighted that homeless persons are compelled to live in public spaces and criminalizing a compelling condition goes against the constitutional principle of the rule of law and the National Avowal of the Fundamental Law. In the constitutional complaint, the referring court argued that the Seventh Amendment of the Fundamental Law introduced solely a general prohibition of homelessness, which by itself would not require a separate legal provision criminalizing homelessness. As such, the Kaposvár court argued that the blanket criminalization of homelessness is not necessary because the legislation already criminalizes as separate offences certain behaviours that might be connected to homelessness and present a social danger, such as loitering in public and disturbing the public peace. Finally, the Court argued that the mandatory detention of persons in these cases is discriminatory. ${ }^{76}$

Following a similar line of reasoning, the Szekesfehérvár Court argued that the legal framework of the offence procedure is not suitable for the court to examine under what circumstances the person subject to the proceedings has been compelled to live in public spaces, and whether this occurrence can be attributable to the person. Moreover, according to the court, it cannot be established to what extent the right to self-determination, as part of the principle of human dignity, plays a role in these events. As an additional consideration, the court highlighted that it must be taken into account that there can be various compelling reasons for not using homeless shelters, such as in the cases of infectious diseases. Finally, this court referred to the mandatory detention provision of the legal offence, which according to the Court goes against the prohibition of degrading treatment. ${ }^{77}$

These questions highlight the virtues of judicial justice and some form of courage, ${ }^{78}$ while at the same time respecting the role of hierarchically superior courts and positive legal rules. They display a concern for balancing the public interest served by the positive rule and respect for the legal position of the victims based on human dignity or the legal definition of homelessness. In doing

75 Act CLI of 2011 on the Constitutional Court of Hungary, Art. 25. Fundamental Law of Hungary, Article 24 (2, b). Eight courts referred a question to the Constitutional Court, http:// public.mkab.hu/dev/dontesek.nsf/0/2BA8668E09472DB8C1258337004BC40A?OpenDocument (accessed 27 September 2019).

76 Constitutional question by Kaposvár First Instance Court, (http://public.mkab.hu/dev/ dontesek.nsf/0/2ba8668e09472db8c1258337004bc40a/\%24FILE/

III_1628_0_2018_inditvany_anonim.pdf) (accessed 27 September 2019).

77 Constitutional question by the Szekesfehérvár First Instance Court, http://public.mkab.hu/dev/ dontesek.nsf/0/6add5f8090b38b6bc1258352003b880e/\$FILE/III_1727_0_2018_ind \%C3\%ADtv\%C3\%A1ny_anonim.pdf (accessed 27 September 2019). cf. Van Domselaar, 'Moral Quality in Adjudication' (2015), 31, 32, 33. 
so, the questions indicate a concern about the possible arbitrary exercise of public power, and perversion of criminal law, raised by the criminalization of homelessness. This is in line with the constitutional value of the rule of law. At the same time, the formulation of these questions also highlights the tension between upholding the rule of law value and closely following the rationale of the applicable legal provisions, as expected by the modified constitutional frame of reference.

However, the Constitutional Court in its 2019 decision rejected the concerns raised by judges. ${ }^{79}$ With this judgment the Constitutional Court upheld the constitutionality of Article XXIII and 178/B of the Offences Act in light of the modified constitutional frame of reference. According to the majority of Constitutional Court judges, the value of human dignity refers to the 'dignity of an individual living in a society and bearing the responsibility of social coexistence'. ${ }^{80}$ In doing so, the Constitutional Court approached the value of human dignity as being closely intertwined with the obligations of citizens. In the opinion of the Court, in case a person does not cooperate with the State in securing housing, the constitutional protections cease to be applicable. ${ }^{81}$ As such, the enjoyment of the fundamental rights guaranteed in the Fundamental Law is dependent on the fulfillment of the constitutional duties of a person. In comparison with the 2012 decision $^{82}$ and on the basis of the modified constitutional text, ${ }^{83}$ the Constitutional Court created a significantly different reading of the underlying value of human dignity.

Furthermore, the Constitutional Court indicated three requirements for judges in the application of the law. In individual cases, it must be assessed (1) whether there is available space in homeless shelters to accommodate the person in question, (2) whether the police have issued the required three warnings and (3) whether a social worker was present during the proceedings. Provided these procedural conditions are met, the legal provision criminalizing homelessness becomes applicable with no further room for balancing. Indeed, in line with this strict reading, the additional information requested by the Constitutional Court from the Ministry of Justice, the Human Resources Ministry, the 'Foundation for the Homeless' (Hajléktalanokért Közalapítvány), the Menhely Foundation (Menhely Alapítvány) and the Hungarian Charity Service of the Order of Malta (Magyar Máltai Szeretetszolgálat) referred solely to the number of available places in homeless shelters. However, the Constitutional Court did not inquire into the quality of these spaces.

Remarkably, the Decision of the Constitutional Court also makes direct reference to the obligation of judges to interpret the applicable provisions of the Offences

79 Constitutional Court of Hungary, Decision 19 of 2019 (VI.18.) AB.

80 Ibid., para. 103.

81 Ibid, para. 101.

82 Constitutional Court of Hungary, Decision 38 of 2012 (XI.14.) AB.

83 See above 2018 modifications concerning criminalization of homelessness. Seventh Amendment of the Fundamental Law, 28 June 2018, Art. 6. 
Act in line with the requirements of Article 28 of the Fundamental Law. ${ }^{84}$ The argumentation of the Constitutional Court recalled that the interpretation of the legal act in compliance with Article 28 constitutes a 'constitutional order (command)' for judges. In the opinion of the Constitutional Court, the legislation provides for a flexible balancing possibility in the application of the law, in the sense of establishing the meaning of 'habitual'. However, at the same time, the Court also explicitly pointed out that 'cleaning oneself in a public space is not inherent to the intended aim and use of public spaces' ${ }^{85}$ To these observations the Constitutional Court added that it is for the courts to determine the applicable interpretative frameworks.

With this judgment by the Constitutional Court, the room for judges to decide in line with their conscience ${ }^{86}$ has been reduced. For instance, in the factual assessment of conditions, the Constitutional Court only refers to the possibility to evaluate the availability of space in homeless shelters. As such, judges are not permitted to assess the quality of these spaces - an aspect raised by the courts introducing the constitutional complaint. ${ }^{87}$ Furthermore, the interpretational room is reduced to the notion of 'habitual' dwelling and, overall, these findings are reinforced with the reference to the mandatory nature of Article 28. In light of the above limitations, the question occurs to the extent these legal developments contribute to the incremental and context-specific realization of the rule-of-law. Moreover, what is the legitimate space and platform available to judges to reflect on these tensions?

\section{Criminalization of Homelessness in Light of the Progressive and Context- Specific Realization of the Rule-of-Law Ideal}

From the perspective of the progressive and context-specific realization of the ideal of the rule of law, ${ }^{88}$ the Hungarian case of criminalization of homelessness confirms broader trends of 'rule of law backsliding. ${ }^{89}$ Indeed, the constitutional

84 See above, section 2 of this article.

85 Constitutional Court of Hungary, Decision 19 of 2019 (VI.18.) AB, para. 80.

86 See above, sections 2 and 3 of this article.

87 See Constitutional question referred by the Székesfehérvár Court (note 77).

88 Selznick, “'Law in Context” Revisited' (2003), 179. Krygier, 'The Rule of Law. Legality, Teleology, Sociology' (2009), 69, 70. Selznick, 'Legal Cultures and the Rule of Law' (1999), 21-38. Krygier, The Rule of Law. An Abuser's Guide' (2006), 3-24.

89 Pech \& Scheppele, 'Illiberalism Within: Rule of Law Backsliding in the EU (2017). P. Sonnevend, A. Jakab \& L. Csink, 'The constitution as an instrument of everyday party politics: the basic law of Hungary', in eds. A. von Bogdandy \& P. Sonnevend, Constitutional Crisis in the European Constitutional Area. Theory, Law and Politics in Hungary and Romania (C.H. Beck-Hart-Nomos, 2015), 33-110. Z. Szente, 'Challenging the Basic Values - Problems in the Rule of Law in Hungary and the Failure of the EU to Tackle Them'. in eds. A. Jakab \& D. Kochenov, The Enforcement of EU Rules and Values. Ensuring Member State's Compliance (Oxford: Oxford University Press, 2017), 456-476. See K. L. Scheppele, 'Understanding Hungary's Constitutional Revolution', in eds. A. von Bogdandy \& P. Sonnevend, Constitutional Crisis in the European Constitutional Area. Theory, Law and Politics in Hungary and Romania (C.H. Beck-Hart-Nomos, 2015), 112. 
and legal modifications taking place since the Fourth Amendment of the Fundamental Law in 2013 appear to be in stark contrast with the incremental constitutional developments between 1990 and 2011. This previous constitutional frame of reference established the importance of decision-making autonomy of judges and highlighted that this autonomy entails upholding the law and also rendering decisions based on the judges' conscience. ${ }^{90}$ This approach is also reflected in the content of the judicial code of ethics. These legal and institutional developments fit the paradigm of progressive realization of the rule of law. In the Hungarian context, the quality of the previous constitutional framework, the interpretation by the Constitutional Court, the above-discussed scholarly analysis regarding the legitimate interpretational room of judges as well as the non-binding guidance by the judicial code of ethics referring to the importance of fulfilling the constitutional role of judges seemed an enabling factor in realizing the progressive realization of the rule of law value as well as judicial virtues.

However, the explicit constitutional obligation of judges to interpret legal acts since 2018 - by considering not only the Preamble of a legal act, but also the specific legislative preparatory documents - limit the decision-making space for judges. Rather than enabling judges to decide cases independently, professionally, and in line with their conscience and ethical values, it forces judges to adhere to the specific values and considerations of the legislators. ${ }^{91}$

As argued above, on the one hand, the constitutional changes raise the problem of moving towards a system of subjective teleological interpretation. On the other hand, the modified content of the constitution creates tension for judges in the sense of following ethical and rule of law values. For instance, the reference in the ethical code to the 'constitutional role of judges' implicitly refers to upholding the rule of law value but also to the partially competing values of 'moral, economic and rational purposes' of legal rules and the Christian values prescribed by the Fundamental Law. In these circumstances, relying on judicial virtues, such as courage and judicial justice could theoretically be useful for judges to legitimately distance themselves from legislation that goes against the rule of law value. However, the realization of these virtues seems to face significant obstacles in practice.

Regarding the criminalization of homelessness, a specific cause for concern is that Article 28 limits the possibilities of ordinary and constitutional court judges to uphold the constitutional rule of law value and to legitimately speak up against the application of a legislation that raises rule of law concerns. Two possibilities available for judges to address these tensions were to rely on the legitimate interpretational room in their decision-making process or to address a question

90 Cf. L. Sólyom, 'The Role of Constitutional Courts in the Transition to Democracy: With Special Reference to Hungary', International Sociology 18 (2003), 1, 133-161, 150-153.

91 Cf. Zs. Körtvélyesi \& B. Majtényi, 'Game of Values: The Threat of Exclusive Constitutional Identity, the EU and Hungary’, German Law Journal 18, no. 7 (2017), 1721-1744. 
to the Constitutional Court. ${ }^{92}$ However, following the 2019 decision by the Constitutional Court both of these possibilities are limited. Indeed, the 2019 decision explicitly limited the interpretational room of judges to the notion of 'habitual'. Moreover, the decision reversed the previous dignity-based interpretation of homelessness and introduced a constitutional reading rooted in the duties and obligations of citizens. With this decision, explicitly connected to Article 28, the Constitutional Court offered a close reading of the modified constitutional text. ${ }^{93}$ In doing so, the Constitutional Court hindered rather than contributed to the realization of a legitimate interpretational room for judges. Here, the changes in the content of the constitutional rules, but also in the position of the Constitutional Court, serve as limiting factors.

A further possibility for judges would be to address these tensions as part of reflections concerning the content of the judicial code of ethics, thus enhancing moral and rule of law quality. However, in light of the process of adoption of the 2015 ethical code, this too appears limited. Whereas the 2005 code of judicial ethics was adopted by the judicial association and with the participation of judges, the 2015 did not offer such automatic guarantees. The 2015 judicial code of ethics offers some form of representation by ultimately being adopted by the National Judicial Council, a collegial body composed of judges. Nonetheless, the involvement of judicial associations with wider membership was excluded. This goes against broader European developments in the fields of judicial ethics where judges and judicial associations actively participate in the development of ethical values. ${ }^{94}$ As a further European practice we can mention the publication of the outcome of such critical reflections as explanatory guidelines containing practical examples. ${ }^{95}$ Such guidelines are missing from the Hungarian context. With these omissions, the Hungarian changes seem to move away from European developments and they do not signal openness to constructive dialogue. This too is problematic from the perspective of the progressive and context-specific realization of the rule of law, as it appears as a regression rather than part of progressive realization of the rule of law.

92 Act CLI of 2011 on the Constitutional Court of Hungary, Art. 25. Fundamental Law of Hungary, Art. 24 (2, b).

93 Cf. N. Chronowski \& M. Varju, 'Two Eras of Hungarian Constitutionalism: From Rule of Law to Rule by Law', Hague Journal on the Rule of Law 8, no. 2 (2016), 271-289.

94 See e.g. NvVR, 'Guide to Judicial Conduct of the Dutch Association of Judges', in Matters of Principle. Codes on the Independence and Impartiality (https://www.rechtspraak.nl/ sitecollectiondocuments/matters-of-principle.pdf) (accessed 27 September 2019), 87-125. Norwegian Association of Judges, Tekna's Sector Union for the Land Consolidation courts and the National Courts Administration, 'Ethical Principles for Norwegian Judges', www.juristforbundet.no/globalassets/dokumenter/organisasjon/dommerforeningen/ethicalprinciples-for-the-proper-conduct-of-norwegian-judges.pdf (accessed 27 September 2019).

95 See e.g. I. Copoeru, B. Maan, I. Huitfeldt \& T. Gundersen, 'Ghid practic de etică profesională pentru judecători și procurori (Practical guide of professional ethics for judges and prosecutors),' (Bucharest 2017) www.inm-lex.ro/fisiere/d_2010/Ghidul\%20practic\%20de\%20etica \%20profesionala\%20pentru\%20judecatori\%20si\%20procurori.pdf (accessed 27 September, 2019). NvVR, 'Guide to Judicial Conduct of the Dutch Association of Judges', 127-169. 


\section{Conclusion}

This article set out to investigate the nature and extent of tensions raised by the criminalization of homelessness in Hungary between the constitutional obligation of judges to uphold the law and the professional requirement of judges to decide cases based on ethical values and the rule of law. As the analysis showed, currently, tension exists between the role of judges to interpret legislation pursuant to Articles 28 and R of the Fundamental Law, and the decision-making autonomy of judges, which in the traditional Hungarian context includes both the obligation to uphold rules of positive law and the possibility of judges to decide cases based on their conscience and in line with the rule of law. The amplification of this tension is closely connected to subsequent constitutional modifications reducing the legitimate interpretational room for judges to address constitutional concerns and thus uphold the rule of law.

Possible lessons can be drawn from this analysis relating to judicial virtues. Firstly, the text of a constitution can be used to disable judicial virtues such as judicial courage and limit judicial justice. Secondly, in rule of law backsliding contexts, the implicit reference in judicial codes of ethics to the main role of the judiciary to uphold the rule of law may work to the detriment of enabling courage and judicial justice. In a similar vein, lack of possibilities to critically reflect on the content of ethical codes may have a deleterious effect on the development of judicial virtues. Regarding the criminalization of homelessness, a specific cause for concern is that this criminalization represents a perversion of criminal justice by inappropriately criminalizing behaviour, which pertains to the field of social problems. Here, the exercise of judicial virtues could be of key importance. However, the above-described changes limit such exercise.

At the same time, the analysis also tested the continued applicability of the theoretical framework of progressive reduction of arbitrariness in the exercise of public power and context-specific understanding of the rule of law ideal, originally developed by Selznick and Krygier. Overall, the theoretical framework conceptualizing rule of law development as a long-term, ever-increasing exercise, which might entail progressive as well as regressive periods or decays, has its merit of providing a global and long-term overview and understanding of rule of law development. However, when addressing 'rule of law backsliding', such as the case discussed in this analysis, parts of the theoretical approach seem to face limitations. Indeed, a potential limitation of the theory is that the acknowledgement of the possibility of regressions remains very implicit. Therefore, the framework does not provide guidance in the sense of how to reverse or bounce back from regressive periods. In light of these limitations, it would appear beneficial to refine our theoretical understanding as more explicitly including regressions. Here, socio-legal analysis concerning international courts, in particular placing the principled resistance against the European Court of Human Rights into a more long-term perspective of using frictions as part of 
broader re-legitimization processes of an institution, could be useful. ${ }^{96}$ Moreover, more theoretical attention could be dedicated towards building resiliency of rule of law institutions.

96 M. Rask Madsen, 'Resistance to the European Court of Human Rights: The Institutional and Sociological Consequences of Principled Resistance', in ed. M. Breuer, Principled Resistance to ECtHR Judgments - A New Paradigm? (Berlin: Springer 2019), 35-52. 